\title{
Subcellular location of XpsD, a protein required for extracellular protein secretion by Xanthomonas campestris pv. campestris
}

\author{
Nien-tai Hu, ${ }^{1}$ Ming-Ni Hung, ${ }^{1}$ Chao-Tsai Liao ${ }^{1,2}$ and Ming-Huei Lin ${ }^{1,3}$
}

Author for correspondence: Nien-tai Hu. Tel: +886 4 2874754. Fax: +88642861905.

e-mail: 711nthu@vax9K.nchu.edu.tw

Agricultural Biotechnology Laboratories', Graduate Institute of Molecular Biology2 and Graduate Institute of Botany3, National Chung Hsing University, 250 Kuo Kuang Road, Taichung, Taiwan 40227, Republic of China

\begin{abstract}
The last ORF of an Xps gene cluster, designated XpsD, is required for the secretion of extracellular enzymes across the outer membrane in Xanthomonas campestris pv. campestris. It could encode a protein of 759 amino acid residues. A consensus $\mathbf{N}$-terminal lipoprotein signal peptide was revealed from its deduced amino acid sequence. A [ $\left.{ }^{3} \mathrm{H}\right]$ palmitate labelling experiment indicated that XpsD was fatty-acylated. Differential extraction with Triton X100 disclosed that XpsD was fractionated with the outer membrane. Sucrose gradient sedimentation analysis of total membranes also indicated that XpsD was mainly located in the outer membrane. At least part of XpsD is exposed to the cell surface as suggested by trypsin experiment results. Intact cells pretreated with antibody against XpsD could indirectly be labelled with fluorescent agent. When the $\mathbf{N}$-terminal lipoprotein signal peptide was replaced with a nonlipoprotein signal peptide cleavable by signal peptidase $\mathrm{I}$, non-fatty-acylated XpsD was synthesized. Its subcellular location was indistinguishable from that of the fatty-acylated XpsD. Complementation of an XpsD:: Tn5 mutant of $X$. campestris pv. campestris indicated that this nonfatty-acylated XpsD remains functional in extracellular protein secretion. $A$ stable, C-terminal truncated protein, XpsD $\Delta$ 414-759, was synthesized from a mutated XPsD gene. Although it stayed associated with the outer membrane and exposed to the cell surface, it no longer could complement the xpsD::Tn5 mutant of $X$. campestris pv. campestris.
\end{abstract}

Keywords: Xanthomonas campestris pv. campestris, general secretion pathway, outermembrane protein, lipoprotein, main terminal branch

\section{INTRODUCTION}

Extracellular proteins synthesized in Gram-negative bacteria have to cross two membrane barriers before being secreted. In some cases, independent of an $\mathrm{N}$-terminal signal peptide, the secretion is accomplished in one step, for instance, the secretion of $\alpha$-haemolysin by Escherichia coli (Holland et al., 1990), proteases by Erwinia chrysanthemi (Létoffé et al., 1990) and alkaline protease by Pseudomonas aeruginosa (Guzzo et al., 1991). In other cases, proteins are secreted via a general secretory pathway in two steps: they reach the periplasm via the general export pathway before they are translocated across the outer membrane (Wandersman, 1992; Pugsley, 1993). An N-terminal signal peptide is processed when the preprotein is being exported across the inner membrane. Fourteen proteins encoded by the pulC-O and pulS genes of Klebsiella oxytoca are required for the secretion of pullulanase across the outer membrane (reviewed by Pugsley et al., 1990). Homologues of pul genes required for the secretion of various extracellular enzymes have since been found to be widespread among different plant and animal pathogens. These homologues include $x p s$ genes of Xanthomonas campestris pv. campestris (Dums et al., 1991; Hu et al., 1992a), out genes of E. chrysanthemi (Condemine et al., 1992; He et al., 1991; Lindeberg \& Collmer, 1992) and Erwinia carotovora (Murata et al., 1990; Reeves et al., 1993), $x c p$ genes of $P$. aeruginosa (Filloux et al., 1990; Bally et al., 1991, 1992; Akrim et al., 1993) and exe genes of Aeromonas bydrophila (Jiang \& Howard, 1992; Howard et al., 1993). A third secretory pathway (Salmond \& Reeves, 1993; Van Gijsegem et al., 1993) was observed in the secretion of Yop proteins by Yersinia enterocolitica (Michiels et al., 1991), in harpin secretion by Erwinia amylovora (Wei et al., 
1992) and by Pseudomonas syringae (He et al., 1993), in PopA secretion by Pseudomonas solanacearum (Arlat et al., 1994) and in secretion of Ipa proteins by Shigella flexneri (Allaoui et al., 1992, 1993). This type of pathway is similar to the one-step pathway in its independence of an $\mathrm{N}$-terminal signal peptide. On the other hand, one of the determinants required for this pathway (YscC, $\mathrm{HrpH}, \mathrm{HrpA}$ and $\mathrm{MxiD}$ ) is analogous to one component of the two-step pathway, the PulD protein of K. oxytoca (d'Enfert et al., 1989) and its homologues.

$X$. campestris pv. campestris causes black tot in the crucifers. Nonpathogenic Tn 5 mutants have been isolated and demonstrated to be defective in the secretion of extracellular enzymes, which include polygalacturonate lyase, $\alpha$-amylase, protease and endogluconase ( $\mathrm{Hu}$ et al., 1992a). Cloning and sequencing of the genes complementing the secretion-defective mutants revealed an $x p s$ gene cluster (Dums et al., 1991; Hu et al., 1992a). The last ORF, designated $x p s D$, of the gene cluster could encode a protein composed of 759 amino acid residues. Examination of its amino acid sequence disclosed near its $\mathrm{N}$ terminus a stretch of hydrophobic amino acid residues followed by a conserved lipoprotein signal peptide cleavage site, $-\mathrm{LAG} \downarrow \mathrm{C}-$, that would be cleaved by leader peptidase II and modified with lipid at $C$ (cysteine), the first amino acid residue of the mature protein (Hayashi \& Wu, 1990). More than ten bacterial or phage proteins which are required for various biological functions share significant sequence homology with the mature $\mathrm{XpsD}$ (Pugsley, 1993; Russel, 1994). Among them, subcellular location of $K$. oxytoca PulD and the filamentous phage protein $\mathrm{pIV}$, which is required for phage morphogenesis, have been carefully studied. PulD analysed on sucrose gradients was mainly detected in the outer membrane (d'Enfert et al., 1989). On the other hand, filamentous phage pIV was clearly observed in both inner and outer membranes when analysed on sucrose gradients (Brissette \& Russel, 1990) or fractionated with Triton X-100 (Russel \& Kaźmierczak, 1993). Recent studies by Kaźmierczak $e t$ al. (1994) further suggested that pIV may form a multimer. Secondary structure prediction indicated that $\mathrm{XpsD}$ is rich in amphipathic $\beta$-sheets, which were demonstrated to be involved in outer-membrane integration of porins (Weiss et al., 1991; Cowan et al., 1992).

In this study, we determined the subcellular location of $\mathrm{XpsD}$ in its original host $X$. campestris pv. campestris and demonstrated that its fatty acylation is not required for its correct subcellular location or its role in extracellular protein secretion. In contrast, a truncated protein, $\mathrm{XpsD} \Delta 414-759$, was no longer functional in protein secretion, despite its association with the outer membrane.

\section{METHODS}

Bacterial strains, plasmids and media. Xanthomonas campestris pv. campestris $x p s D:: \operatorname{Tn} 5$ mutant $\mathrm{XC1708}$ was constructed previously in this laboratory (Hu et al., 1992a). The broad-hostrange vector $\mathrm{PCPP} 30$ was kindly provided by David Bauer (Department of Plant Pathology, Cornell University, Ithaca, NY, USA). The plasmid pKC107 contains a $6.4 \mathrm{~kb}$ EcoRI-
BstEII fragment from $X$. campestris pv. campestris, which includes the wild-type $x p s D$ gene, in pCPP30. The same fragment cloned in a phagemid pSelect-1 was designated pKC101. The plasmids $\mathrm{pMH} 9$ and $\mathrm{pKC118}$ each contain the complete $x p s D$ gene alone downstream of the lac promoter on vectors pTZ18U (Mead et al., 1986) and pCPP30, respectively. The plasmid pCT1 was constructed by cloning a BamHI fragment of the $x p s D$ gene at the BamHI site of pTZ19U (Mead et al., 1986) downstream of the lac promoter. The plasmid $\mathrm{pMH} 7$ was acquired by cloning a C-terminal truncated $x p s D$ gene $(x p s D 4414-759)$ in pCPP30. The plasmid pCD105 was obtained by cloning the truncated $x p s D 428-427$ gene in pCPP30. The plasmid p18UA5 contains the complete amy gene on a $1.8 \mathrm{~kb}$ EcoRI fragment cloned in pTZ18U. The plasmid pCT5 was constructed by ligating the EcoRI fragment of pCT3, which contains a chimeric amy-xpsD gene, with pCPP30. The SOE (gene splicing by overlap extension) strategy of Horton $e t$ al. (1989) was followed in the construction of PCT3.

Four oligomers designated ' $a$ ', ' $b$ ', ' $c$ ' and 'd' were synthesized for conducting polymerase chain reactions (PCR). For the synthesis of an 'amy' fragment, p18UA5 was included as the template, and oligomers ' $a$ ' (5'-CGCCAGGGT'TT'TCCCAGTCACGAC-3') and ' $b$ ' (5'-AGTGGTGGCGATGACGTCGGCCTGTGCGCT-3') were used as primers. This ' $a m y$ ' fragment contains the nucleotide sequence encoding the signal peptide plus the first three amino acid residues of the mature protein of $\alpha$-amylase, and the $5^{\prime}$ flanking sequence which includes the promoter region of the amy gene (Hu et al., 1992b). In a separate tube, pKC101 was included as template and oligomers ' $c$ ' (5'-GACGTCATCGCCACCACTCCGCCACCGGA-3') and ' $d$ ' ( 5 '-TCAGCGGCACCACGCGCACCTCGA$3^{\prime}$ ) were used as primers for the synthesis of an ' $x p s D$ ' fragment which contains the nucleotide sequence encoding the $\mathrm{N}$ terminus of the processed $\mathrm{XpsD}$ protein minus its first amino acid residue, cysteine. Primers ' $b$ ' and ' $c$ ' were so designed that 18 nucleotides on the $5^{\prime}$ end of each are complementary to each other. The 'amy' and the ' $x p s D$ ' fragments, recovered from the agarose gel slices using Geneclean, were mixed and underwent six cycles of PCR $\left(94^{\circ} \mathrm{C}\right.$ for $1 \mathrm{~min} 30 \mathrm{~s}, 37^{\circ} \mathrm{C}$ for $2 \mathrm{~min}$ and $58^{\circ} \mathrm{C}$ for $3 \mathrm{~min}$ ) before primers ' $a$ ' and ' $d$ ' were added for an additional 30 cycles of PCR $\left(94^{\circ} \mathrm{C}\right.$ for $1 \mathrm{~min}, 60^{\circ} \mathrm{C}$ for $2 \mathrm{~min}$ and $72{ }^{\circ} \mathrm{C}$ for $1 \mathrm{~min}$ for all cycles except the last one, which was $72^{\circ} \mathrm{C}$ for $2 \mathrm{~min}$ ). An ' $a m y-x p s D$ ' fragment of $1 \mathrm{~kb}$ was generated from this PCR. It was recovered from the agarose gel, digested with HindIII and SacII and ligated with pKC101 digested with the same enzymes.

M9 medium, M9 salts, L-broth and L-agar were prepared according to Miller (1972). The XOL medium for growing $X$. campestris pv. campestris was prepared as reported before ( $\mathrm{Hu}$ et al., 1992a). Antibiotics were added where appropriate at the following concentrations: tetracycline, $15 \mu \mathrm{g} \mathrm{ml}^{-1}$; ampicillin, $50 \mu \mathrm{g} \mathrm{ml}^{-1}$; rifampicin, $100 \mu \mathrm{g} \mathrm{ml}^{-1}$; and kanamycin, $50 \mu \mathrm{g}$ $\mathrm{ml}^{-1}$.

Site-directed mutagenesis. The site-directed in vitro mutagenesis with the Altered Sites System purchased from Promega was used in creating $X b a I$ sites in the $x p s D$ gene for the construction of $x p s D \Delta 28-427$ and $x p s D \Delta 414-759$ genes. Singlestranded template was generated by superinfecting an $E$. coli strain containing the complete $x p s D$ gene cloned in the phagemid pSelect-1 with a helper phage, M13KO7 (Vieira \& Messing, 1987). Two primers were used in the construction of the mutant $x p s D \Delta 28-427$ gene: 5'-TCGCGGCGCACGTCTAGAGGCGGAGTGGTGG-3' for the upstream XbaI site and 5'-GTAACGCTACCGTTCTGGTCTAGACTAGGCGG-3' for the downstream $X b a I$ site. A single primer with the following sequence was used in the construction of the mutant 
$x p s D 414-759$ gene: 5'-TGCCGCTACTTCCGTCTAGAAGCTCCCTGACG-3'.

Production of antibody against LacZ-XpsD fusion protein. $E$. coli JM101(pCT1) grown in L-broth containing $50 \mu \mathrm{g}$ ampicillin $\mathrm{ml}^{-1}$ to $\mathrm{OD}_{600} 0.4$ was induced with $0.3 \mathrm{mM}$ IPTG for $2 \mathrm{~h}$. Total cell lysates were prepared by treating with $1 \mathrm{mg}$ lysozyme $\mathrm{ml}^{-1}$ in $20 \mathrm{mM}$ Tris $/ \mathrm{HCl}, \mathrm{pH} 7.0,1 \mathrm{mM}$ EDTA on ice for $30 \mathrm{~min}$, followed by sonication, and electrophoresed in an SDSpolyacrylamide gel containing $8 \%(\mathrm{w} / \mathrm{v})$ acrylamide: $N, N^{\prime}$ methylene bisacrylamide $(29: 1, \mathrm{w} / \mathrm{w})$. The major band containing the overproduced LacZ-XpsD fusion protein was collected for immunizing the rabbit. One hundred and fifty micrograms of the fusion protein was injected each time. Sera prepared following the procedures of Harlow \& Lane (1988) were stored at $-70^{\circ} \mathrm{C}$ and tested subsequently for antibody in immunoblot analysis.

Western blot and immunodetection. Proteins separated in SDS-polyacrylamide gels were electroblotted onto nitrocellulose membranes with transfer buffer $(192 \mathrm{mM}$ glycine, $25 \mathrm{mM}$ Tris/ $\mathrm{HCl}, \mathrm{pH} 8 \cdot 3,20 \%, \mathrm{v} / \mathrm{v}$, methanol). The blot, after having been treated with blocking buffer $(5 \%$, w/v, nonfat milk powder in $150 \mathrm{mM} \mathrm{NaCl}, 1 \mathrm{mM}$ EDTA, $50 \mathrm{mM}$ Tris/ $\mathrm{HCl}$, $\mathrm{pH} 7 \cdot 4,0.05 \%, \mathrm{v} / \mathrm{v}$, Tween 20 ), was reacted overnight at room temperature with the antiserum raised in rabbit against the LacZ-XpsD fusion protein (1:1000 dilution) and detected with the second antibody against rabbit IgG conjugated to peroxidase.

[ $\left.{ }^{3} \mathrm{H}\right]$ Palmitate labelling. $X$. campestris pv. campestris, grown in $\mathrm{XOL}+0.5 \%$ maltose to $\mathrm{OD}_{600} 0.8$, was labelled with $200 \mu \mathrm{Ci}$ $(7400 \mathrm{kBq}) \quad\left[9,10{ }^{-3} \mathrm{H}\right]$ palmitic acid $\mathrm{ml}^{-1} \quad\left(55 \mathrm{Ci} \mathrm{mmol}^{-1}\right.$; $2035 \mathrm{GBq} \mathrm{mmol}^{-1}$ ) for $2 \mathrm{~h}$ at $28^{\circ} \mathrm{C}$. Labelling was stopped with an equal volume of cold $10 \%(\mathrm{w} / \mathrm{v})$ trichloroacetic acid (TCA). After having been left on ice for $10 \mathrm{~min}$, the mixture was centrifuged $(7000 \mathrm{~g})$ at $4{ }^{\circ} \mathrm{C}$ for $1 \mathrm{~min}$. The precipitate was then washed twice with cold acetone, dried and boiled in lysis buffer (10 mM Tris/HCl, pH 7·5, $1 \mathrm{mM}$ EDTA, $1 \%$, w/v, SDS) for $10 \mathrm{~min}$. After centrifugation at $7000 \mathrm{~g}$ for $10 \mathrm{~min}$, the supernatant was transferred to a new tube and saved as labelled cell lysate at $-20^{\circ} \mathrm{C}$.

Immunoprecipitation. Labelled cell lysates were reacted with antiserum against the LacZ-XpsD fusion protein (at 1:600 dilution) alone, or plus the antiserum against E. coli OmpA (at $1: 8000$ dilution), in Triton buffer $(2 \%, v / v$ Triton $\mathrm{X}-100$, $50 \mathrm{mM}$ Tris/HCl, pH 7.5, $150 \mathrm{mM} \mathrm{NaCl}, 0.1 \mathrm{mM}$ EDTA) at $4^{\circ} \mathrm{C}$ overnight. Seventy-five microlitres of protein A-Sepharose $\mathrm{CL}-4 \mathrm{~B}(10 \%, \mathrm{w} / \mathrm{v}$, in Triton buffer) was then added and incubated for another hour at $4{ }^{\circ} \mathrm{C}$. After centrifugation at $7000 \mathrm{~g}$ for $1 \mathrm{~min}$, the pellet was washed twice with Triton buffer and once with $10 \mathrm{mM}$ Tris $/ \mathrm{HCl}, \mathrm{pH} 8 \cdot 0$. The washed pellet was boiled in electrophoresis sample buffer for $5 \mathrm{~min}$. After centrifugation at $7000 \boldsymbol{g}$ for $10 \mathrm{~min}$, the supernatant was ready for SDS-PAGE. When the electrophoresis was finished, the gel was soaked in Enlightning autoradiography enhancer (Du Pont NEN Research Products) at room temperature with shaking for $30 \mathrm{~min}$, dried and exposed to X-ray film at $-70^{\circ} \mathrm{C}$.

Proteinase $\mathrm{K}$ or trypsin treatment of intact cells. Early exponential phase cultures $\left(\mathrm{OD}_{600}=0.6\right)$ were used for proteinase $\mathrm{K}$ or trypsin experiments. E. coli was pregrown in M9 minimal salts with $0.4 \%$ glucose and $0.5 \%$ Casamino acids. Before labelling the cells were washed with M9 salts and incubated at $37^{\circ} \mathrm{C}$ for $1 \mathrm{~h}$ in $\mathrm{M} 9$ medium (without Casamino acids) supplemented with $0.3 \mathrm{mM}$ IPTG. For every $1 \mathrm{ml}$ culture, $20 \mu \mathrm{Ci}\left[{ }^{35} \mathrm{~S}\right]$ methionine $(740 \mathrm{kBq})\left(>1000 \mathrm{Ci} \mathrm{mmol}^{-1}\right.$; $37000 \mathrm{GBq} \mathrm{mmol}^{-1}$ ) were added. After incubation at $37^{\circ} \mathrm{C}$ for
$30 \mathrm{~min}$, the labelling reaction was stopped by chilling in ice. $X$. campestris pv. campestris was pregrown and labelled in similar conditions, except that M9 salts were replaced with XOL salts and all incubations were performed at $28^{\circ} \mathrm{C}$. The labelled cells were then centrifuged at $7000 \mathrm{~g}$ for $5 \mathrm{~min}$, resuspended in $10 \mathrm{mM} \mathrm{Tris} / \mathrm{HCl}, \mathrm{pH} 7 \cdot 8$, and $10 \mathrm{mM} \mathrm{MgCl}$, and treated with various concentrations of proteinase $\mathrm{K}$ or trypsin on ice for $1 \mathrm{~h}$. Ice-cold $10 \%$ TCA and protease inhibitor (final concentration of $5 \mathrm{mM}$ PMSF in the case of proteinase $\mathrm{K}$; final concentration of $25 \mu \mathrm{g}$ soybean trypsin inhibitor $\mathrm{ml}^{-1}$ in the case of trypsin) were added to stop the reaction. After centrifugation at $7000 \mathrm{~g}$ for $1 \mathrm{~min}$, the TCA precipitates were treated the same way as in the palmitate labelling experiment to obtain the labelled cell lysates, which were immunoprecipitated and electrophoresed as before.

Subcellular fractionation. The periplasmic fraction was collected as the supernatant after centrifugation of spheroplasts, prepared by treating $\mathrm{H}_{2} \mathrm{O}$-washed cells with $1 \mathrm{mg}$ lysozyme $\mathrm{ml}^{-1}$ in $20 \%(\mathrm{w} / \mathrm{v})$ sucrose, $30 \mathrm{mM}$ Tris $/ \mathrm{HCl}, \mathrm{pH} 8 \cdot 0,1 \mathrm{mM}$ EDTA on ice for $1 \mathrm{~h}$, at 12000 r.p.m. for $30 \mathrm{~min}$. Prior to sonication, spheroplasts were washed once with the same buffer without lysozyme and resuspended in $10 \mathrm{mM}$ Tris/ $\mathrm{HCl}, \mathrm{pH} 8 \cdot 0$. The pellet collected after centrifugation of sonicated spheroplasts at 12000 r.p.m. for $30 \mathrm{~min}$ was resuspended in lysis buffer and saved as the membrane fraction, and the supernatant saved as the cytoplasmic fraction. Both periplasmic and cytoplasmic fractions were precipitated with cold $10 \%$ TCA and washed twice with $95 \%(\mathrm{v} / \mathrm{v})$ ethanol before being resuspended in lysis buffer. Proteins solubilized by boiling each fraction in lysis buffer for $3 \mathrm{~min}$ followed by centrifugation at 12000 r.p.m. for $10 \mathrm{~min}$ were separated in SDS-polyacrylamide gels.

\section{Cell disruption and membrane fractionation on a sucrose} gradient. $X$. campestris $\mathrm{pv}$. campestris cells, grown in L-broth to late exponential phase and washed twice with distilled water, were resuspended in $10 \mathrm{mM}$ HEPES, $\mathrm{pH} 7.5$ (approximately $1 \mathrm{ml}$ for $100-150 \mathrm{mg}$ wet wt cells), plus DNase $\left(50 \mu \mathrm{g} \mathrm{m}^{-1}\right)$ and RNase $\left(50 \mu \mathrm{g} \mathrm{ml}^{-1}\right)$, and disrupted by passing through a French pressure cell at $18000-20000$ p.s.i. $(124 \cdot 2-138 \mathrm{MPa})$ twice. Unbroken cells were removed by centrifugation at $3500 \mathrm{~g}$ for $10 \mathrm{~min}$. Prior to centrifugation, $1 \mathrm{mM} \mathrm{MgCl} 2$ was added. The total membrane preparation was pelleted by centrifugation at $342000 \mathrm{~g}$ for $60 \mathrm{~min}$, washed once with $10 \mathrm{mM}$ HEPES, $\mathrm{pH} 7 \cdot 5$, and resuspended in the same buffer. The concentrated membrane preparation was then loaded on a step sucrose gradient $\left(25-61 \%\right.$, w/w) and centrifuged at $131000 \mathrm{~g}$ for $20 \mathrm{~h}$ at $4^{\circ} \mathrm{C}$. The density of each fraction, collected at $1 \mathrm{ml}$ per fraction, was calculated from the sucrose concentration determined with a refractometer. Samples in alternate fractions were precipitated with cold $5 \%$ TCA, washed twice with ethanol and analysed in SDS-polyacrylamide gels followed by Western blotting and immunodetection.

Differential fractionation of membranes with Triton X-100. The procedure of Russel \& Kaźmierczak (1993) was modified as follows. The total membrane fraction, prepared as described above, except with a pressure of 5000 p.s.i. $(34.5 \mathrm{MPa})$ was resuspended with $1 \%$ Triton X-100, $10 \mathrm{mM} \mathrm{MgCl}, 50 \mathrm{mM}$ Tris/ $\mathrm{HCl}, \mathrm{pH} 8$, and incubated at room temperature for $30 \mathrm{~min}$ followed by centrifugation at $156000 \mathrm{~g}$ for $30 \mathrm{~min}$. The supernatant was precipitated with chloroform/methanol $(1: 2 \cdot 4$, $\mathrm{v} / \mathrm{v})$, resuspended in $4 \% \mathrm{SDS}$ and saved as the inner-membrane fraction. The pellet was extracted again by resuspending with $1 \%$ Triton $\mathrm{X}-100,10 \mathrm{mM}$ EDTA, $50 \mathrm{mM}$ Tris $/ \mathrm{HCl}, \mathrm{pH} 8$, and incubating at room temperature for $30 \mathrm{~min}$ followed by centrifugation at $12000 \mathrm{~g}$ for $1 \mathrm{~h}$. The supernatant from the second extraction was concentrated as before and saved as the 
outer-membrane fraction. The soluble and nonextractable fractions were prepared following the procedure of Russel \& Kaźmierczak (1993).

Immunofluorescence. The procedures of Koehler et al. (1992) were followed with slight modifications. $X$. campestris pv. campestris cells grown in L-broth to $\mathrm{OD}_{600} 0.6$ were washed with PBS ( $8 \mathrm{~g} \mathrm{NaCl}, 0.2 \mathrm{~g} \mathrm{KCl}, 1.44 \mathrm{~g} \mathrm{Na}_{2} \mathrm{HPO}_{4}, 0.24 \mathrm{~g} \mathrm{KH}_{2} \mathrm{PO}_{4} \mathrm{l}^{-1}$, $\mathrm{pH} \mathrm{7.4)}$ plus $10 \mathrm{mM} \mathrm{MgCl}$ three times before suspending in the same buffer. Ten microlitres of washed cells was dropped onto glass slides, air-dried, overlaid with $1 \%(\mathrm{w} / \mathrm{v})$ bovine serum albumin (BSA) and incubated at room temperature for $1 \mathrm{~h}$. The slides were subsequently incubated at room temperature with antibody against the LacZ-XpsD fusion protein (1:100 dilution in PBS + BSA), followed by incubation with goat anti-rabbit IgG antibody conjugated with fluorescein isothiocyanate (FITC) (1:50 dilution in PBS + BSA). Before and after each incubation the slides were washed with water a few times and air-dried. Five microlitres $50 \%(\mathrm{v} / \mathrm{v})$ glycerol was dropped on the slide before it was covered with a cover slip and examined under a fluorescence microscope at $1000 \times$ magnification.

Complementation. The chimeric amy-xpsD gene was tested for its ability to recover the function of a defective $x p s D$ gene by first introducing it into $\mathrm{XC1708}$ via triparental conjugation. The conjugation procedure of $\mathrm{Hu}$ et al. (1992a) was followed. The transconjugants were then examined on XOL medium plus $0.2 \%(\mathrm{w} / \mathrm{v})$ starch for $\alpha$-amylase secretion and on XOL medium plus $0 \cdot 1 \%(\mathrm{w} / \mathrm{v})$ skimmed milk for protease secretion. The parental strain XC1701 was included as a positive control, and $\mathrm{XC1708}$ was included as a negative control.

\section{RESULTS}

\section{Antibody raised against the LacZ-XpsD fusion protein}

A LacZ-XpsD fusion protein with an apparent molecular mass of $68 \mathrm{kDa}$ could be produced from $E$. coli JM101(pCT1). This fusion protein contains the amino acid residues 37-588 of XpsD. Under inducing conditions, the fusion protein represents at least $30-40 \%$ of total protein (not shown). Antibody raised against this fusion protein could detect in the parental strain of $X$. campestris pv. campestris XC1701 a major protein with an apparent molecular mass of $77 \mathrm{kDa}$ and a minor protein of $48 \mathrm{kDa}$ (Fig. 1a, lane 1). Both were observed in $\mathrm{XC1708(pKC118)} \mathrm{as} \mathrm{well,} \mathrm{albeit} \mathrm{in} \mathrm{slightly} \mathrm{different}$ proportions (Fig. 1a, lane 3). In contrast, only the $48 \mathrm{kDa}$ protein was perceived in the $x p s D:: \operatorname{Tn} 5$ mutant XC1708 (Fig. 1a, lane 2). The molecular mass of the $77 \mathrm{kDa}$ protein agrees with what was predicted from the amino acid sequence deduced from the nucleotide sequence of the $x p s D$ gene. However, $\mathrm{XpsD}$ made in $X$. campestris $\mathrm{pv}$. campestris migrated slightly slower than that from $E$. coli (not shown), the cause of which is not clear. Expression of the $x p s D$ gene encoded in $\mathrm{pKC} 118$ is under the control of a lac promoter. However, the expression level of $\mathrm{XpsD}$ in $X$. campestris pv. campestris was not noticeably increased by including the inducer IPTG. Consequently, IPTG was excluded in the following experiments with $X$. campestris pv. campestris. The amount of $\mathrm{XpsD}$ detected in $\mathrm{XC1708(pKC118)} \mathrm{was} \mathrm{approximately} \mathrm{ten} \mathrm{times} \mathrm{that}$ detected in XC1701. (a)

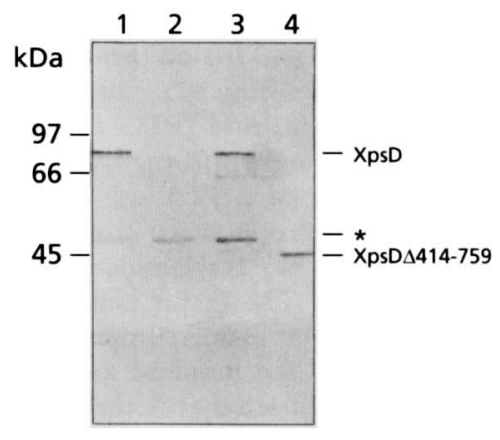

(b)

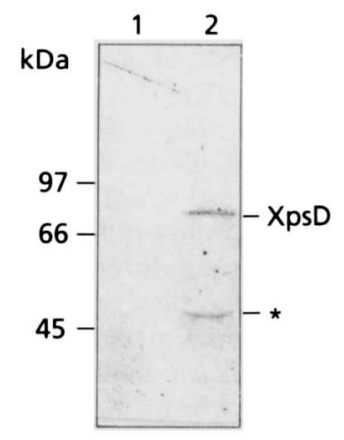

Fig. 1. (a) Detection of XpsD protein in a whole cell extract of $X$. campestris pv. campestris using antibody against the LacZ-XpsD fusion protein. Samples were loaded in the following order. Lanes: 1, XC1701; 2, XC1708; 3, XC1708(pKC118); 4, XC1708(pMH7). One-tenth as many cells were loaded for XC1708(pKC118) and XC1708(pMH7). (b) Autoradiogram of $\left[{ }^{3} \mathrm{H}\right]$ palmitate-labelled $X$. campestris $\mathrm{pv}$. campestris. $X$. campestris pv. campestris XC1708(pCPP30) (lane 1) and XC1708(pKC118) (lane 2), grown in XOL + 0.5\% maltose, were labelled with $\left[{ }^{3} \mathrm{H}\right]$ palmitate for $2 \mathrm{~h}$ at $28^{\circ} \mathrm{C}$. Labelled cell lysates were precipitated with antibody against LacZ-XpsD fusion protein, followed by electrophoresis in an SDSpolyacrylamide gel $(10 \%)$ and fluorography. The $48 \mathrm{kDa}$ protein is designated by *.

\section{[ $\left.{ }^{3} \mathrm{H}\right]$ Palmitate labelling of XpsD}

When $X$. campestris pv. campestris XC1708(pKC118) was labelled with $\left[{ }^{3} \mathrm{H}\right]$ palmitate, followed by immunoprecipitating with antibody against the LacZ-XpsD fusion protein, two protein bands were revealed on the autoradiogram, one with apparent molecular mass of $77 \mathrm{kDa}$ and the other of approximately $48 \mathrm{kDa}$ (Fig. 1b, lane 2). Neither was detected in XC1708 containing the cloning vector pCPP30 (Fig. 1b, lane 1). The $48 \mathrm{kDa}$ protein will be discussed later.

\section{Triton X-100 fractionation of wild-type XpsD}

Differential extraction of membrane vesicles with Triton $\mathrm{X}-100$ revealed that $\mathrm{XpsD}$ synthesized from XC1701 was fractionated with outer-membrane vesicles (Fig. 2). Cofractionated with it was a $44 \mathrm{kDa}$ protein detectable with antibody against the $E$. coli outer-membrane protein OmpA. The major outer-membrane protein OprF of $P$. aeruginosa is also immunologically related to OmpA (Woodruff \& Hancock, 1989; Hancock et al., 1990; Ullstrom et al., 1991). The immunologic relatedness among the three proteins suggested that the $44 \mathrm{kDa}$ protein may be an analogue of OmpA and OprF. We designated this $44 \mathrm{kDa}$ protein OprF. A major portion of OprF was repeatedly observed in the nonextractable fraction. We do not have a good explanation for this observation. We noticed that a minute amount of $\mathrm{OprF}$ was also extracted with inner-membrane vesicles. On the other hand, a major protein of $50 \mathrm{kDa}$ revealed on Coomassie-brilliant-blue-stained gels appeared solely in the inner-membrane fraction (Fig. 2, indicated by an arrowhead). The majority of $\mathrm{XpsD}$ synthesized from 


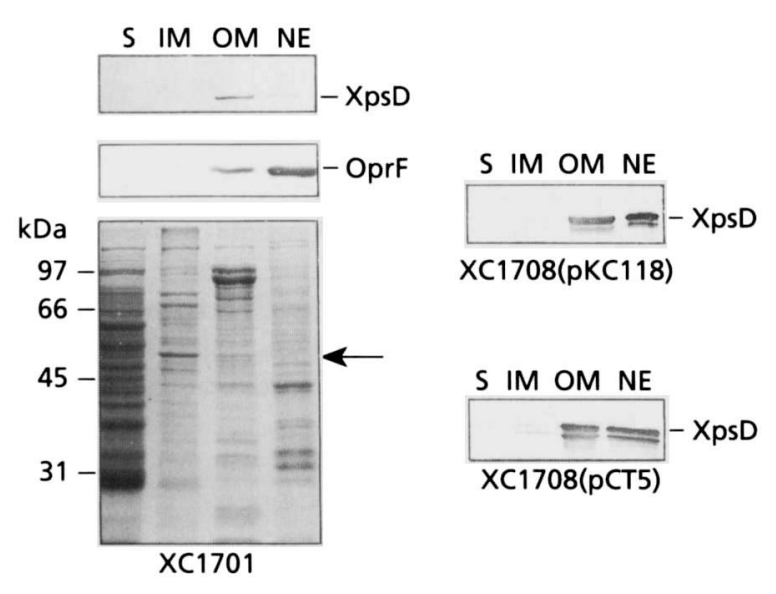

Fig. 2. Triton $X-100$ fractionation of $X$. campestris pv. campestris XC1701, XC1708(pKC118) and XC1708(pCT5). S, soluble proteins (periplasmic plus cytoplasmic); IM, innermembrane proteins; OM, outer-membrane proteins; $N E$, nonextractable proteins. Each fraction was prepared as described in Methods followed by separation in SDS-PAGE. The gel was subsequently stained with Coomassie brilliant blue or transferred to nitrocellulose paper followed by reacting with antibody against LacZ-XpsD fusion protein (labelled XpsD) or antibody against $E$. coli OmpA (labelled OprF) and detection with second antibody conjugated to peroxidase. The arrow points to the $50 \mathrm{kDa}$ protein detected in the inner membrane. Only portions of immunoblots are shown.

$\mathrm{XC1708(pKC118)} \mathrm{was} \mathrm{detected} \mathrm{in} \mathrm{outer-membrane} \mathrm{and}$ nonextractable fractions in almost equal amount (Fig. 2). The minor band migrating faster than the major XpsD observed in XC1708(pKC118) is probably a degradation product.

\section{Sucrose gradient sedimentation analysis of wild-type XpsD}

When total membrane vesicles of the parental strain XC1701 were analysed on sucrose gradients, XpsD was detected in fractions with buoyant densities ranging from $1.145 \mathrm{~g} \mathrm{~cm}^{-3}$ to $1.286 \mathrm{~g} \mathrm{~cm}^{-3}$ (Fig. 3). Likewise, the $44 \mathrm{kDa}$ OprF protein appeared in the same fractions (Fig. 3 ). On the other hand, protein profiles of the fractions with buoyant densities lower than $1.145 \mathrm{~g} \mathrm{~cm}^{-3}$ were distinctly different from those with higher densities. Noticeably, a major protein with an apparent molecular mass of $50 \mathrm{kDa}$ was predominantly present at a density of $1.129 \mathrm{~g} \mathrm{~cm}^{-3}$, where inner-membrane vesicles were expected to appear. Absence of $\mathrm{XpsD}$ in fractions 4-10, where inner-membrane vesicles were expected, indicated that it is not likely to be associated with the inner membrane. Sucrose gradient sedimentation analysis of XC1708(pKC118) resulted in an almost identical distribution of XpsD protein (data not shown), suggesting that overexpression of XpsD did not alter the subcellular location of $\mathrm{XpsD}$ to any significant extent that could be detected on sucrose gradients.

\section{Protease sensitivity of wild-type XpsD in intact cells}

We examined $\mathrm{XpsD}$ protease sensitivity by treating labelled cells with trypsin or proteinase K. In E. coli DH5 $\alpha$ (pMH9), XpsD was degraded completely by treating with $200 \mu \mathrm{g}$ trypsin $\mathrm{ml}^{-1}$ or $1 \mathrm{mg}$ proteinase $\mathrm{K} \mathrm{ml}^{-1}$

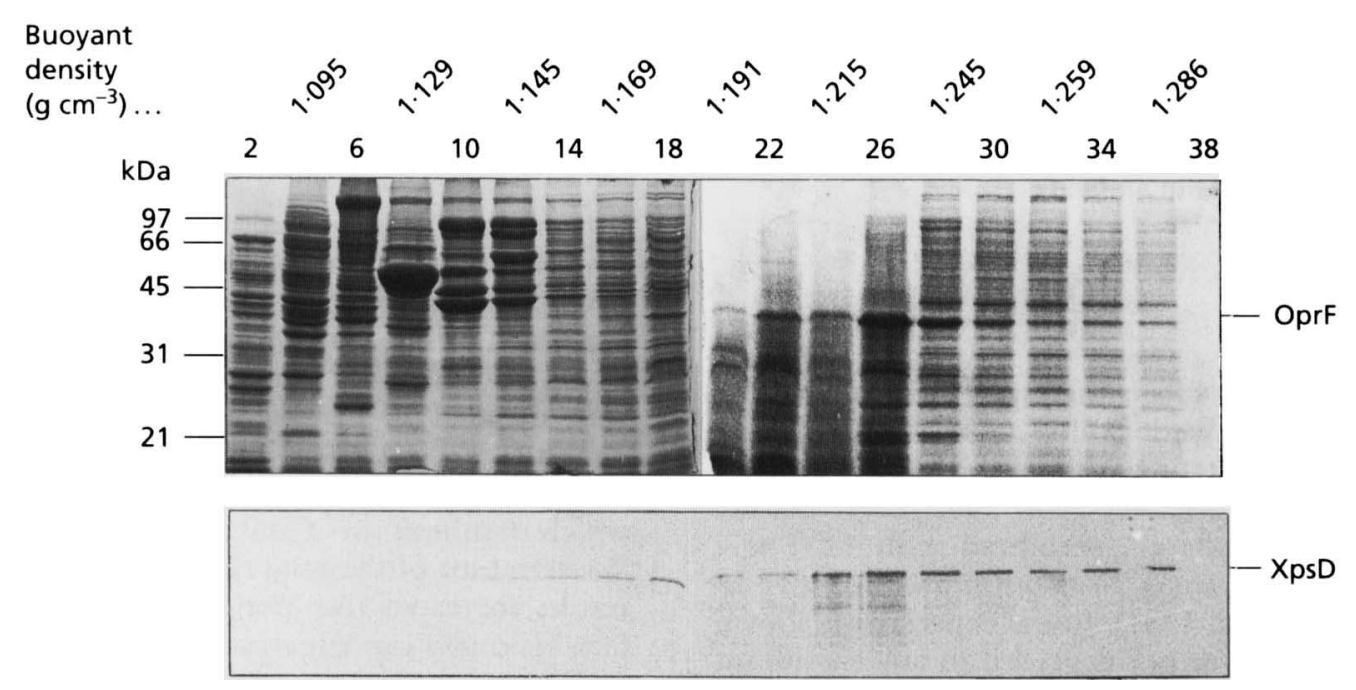

Fig. 3. Sucrose gradient sedimentation analysis of the total membrane preparation of $X$. campestris pv. campestris XC1701. The total membrane fraction, prepared from cells disrupted with a French press, was analysed on a $25-61 \%$ $(w / w)$ sucrose gradient. Concentrated samples from every other fraction were separated in an SDS-polyacrylamide gel. Top panel: gels stained with Coomassie brilliant blue; bottom panel: immunoblots detected with antibody against the LacZ-XpsD fusion protein. In the bottom panel, only the portion where XpsD migrated is depicted. The top of the gradient is on the left. Buoyant densities are shown for the fractions not labelled with fraction numbers. 

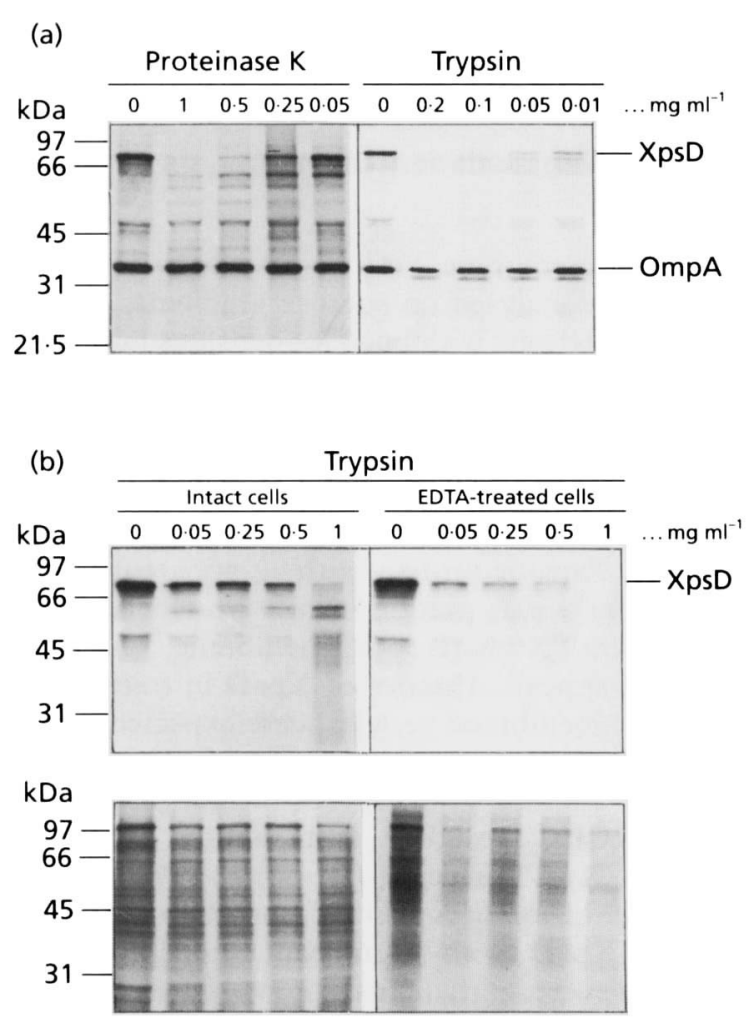

Fig. 4. (a) Protease sensitivity of XpsD in intact E. coli. E. coli DH5 $\alpha$ (pMH9), labelled with [ ${ }^{35} \mathrm{~S}$ ] methionine at $37^{\circ} \mathrm{C}$ for $30 \mathrm{~min}$, was treated with various concentrations of proteinase $K$ or trypsin on ice for $1 \mathrm{~h}$. Protease-treated samples precipitated with antibody against LacZ-XpsD and antibody against $E$. coli OmpA were separated in an SDS-polyacrylamide (10\%) gel. (b) Trypsin sensitivity of $\mathrm{XpsD}$ in $X$. campestris pv. campestris. $X$. campestris pv. campestris XC1708(pKC118), labelled with $\left[{ }^{35} \mathrm{~S}\right]$ methionine at $28^{\circ} \mathrm{C}$ for $30 \mathrm{~min}$, was resuspended in $10 \mathrm{mM}$ Tris/HCl, pH 7.8, with (EDTA-treated cells) or without (intact cells) $5 \mathrm{mM}$ EDTA. Digestions were conducted on ice for $1 \mathrm{~h}$. Trypsin-treated samples, with (top panels) or without (bottom panels) precipitation with antibody against LacZ-XpsD, were separated in an SDS-polyacrylamide $(10 \%)$ gel. The top panels show autoradiograms of immunoprecipitated samples and the bottom panels are Coomassie-brilliant-blue-stained gels of samples not precipitated with antibody.

(Fig. 4a). In order to substantiate the intactness of the protease-treated cells, we included anti-OmpA antibody in the immunoprecipitation reactions. E. coli OmpA is completely resistant to proteases in intact cells. On the other hand, in the cells permeabilized with EDTA, a trypsin-resistant fragment of $24 \mathrm{kDa}$ was produced (Tommassen \& Lugtenberg, 1984). In the experiments shown in Fig. 4(a), OmpA was not degraded to any significant extent at all concentrations of either protease, neither was the $24 \mathrm{kDa}$ protein fragment detected in any trypsintreated sample.

When labelled $X$. campestris pv. campestris

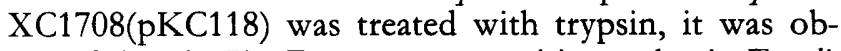
served that the XpsD was not as sensitive as that in E. coli.
Degradation of XpsD was not observed until the concentration of trypsin was raised to $1 \mathrm{mg} \mathrm{ml}^{-1}$ (Fig. $4 \mathrm{~b}$, top, left panel). A dominant fragment of approximately $60 \mathrm{kDa}$ and several minor fragments of smaller sizes were generated (Fig. 4b, top, left panel). In order to ascertain that the degradation of $\mathrm{XpsD}$ caused by treating with $1 \mathrm{mg}$ trypsin $\mathrm{ml}^{-1}$ was not due to cell leakage caused by the high concentration of trypsin, we performed the same control experiments as in the case of E. coli by following the degradation of the $44 \mathrm{kDa}$ protein with anti-OmpA antibody. For unknown reasons, the $44 \mathrm{kDa}$ outermembrane protein in $X$. campestris pv. campestris could not be precipitated with the antibody against E. coli OmpA. To circumvent this problem, we divided all trypsintreated samples into two. The major portion of each sample was immunoprecipitated with anti-LacZ-XpsD antibody as before. The remaining portion was separated in an SDS-polyacrylamide gel without immunoprecipitation and stained with Coomassie brilliant blue. As shown in Fig. 4(b) (bottom, left panel), both the number and densities of the stained proteins in the sample treated with $1 \mathrm{mg}$ trypsin $\mathrm{ml}^{-1}$ were almost identical to those treated with trypsin at lower concentrations. In contrast, in the cells pretreated with $5 \mathrm{mM}$ EDTA, stained protein bands apparently diminished in number and density in all trypsin-treated samples (Fig. 4b, bottom, right panel). At the same time, the trypsin-resistant $\mathrm{XpsD}$ fragments were completely degraded (Fig. 4b, top, right panel). These results suggested that, either in E. coli or in $X$. campestris pv. campestris, some protease susceptible sites of $\mathrm{XpsD}$ are accessible from the exterior of cells.

\section{Immunofluorescence labelling of wild-type XpsD in intact cells}

Antibody labelling experiments were conducted to further examine the likelihood that $\mathrm{XpsD}$ is exposed to the cell surface in X. campestris pv. campestris. XC1708(pKC118) fluoresced, while XC1708 did not. Fluorescence, albeit weak, was also observed in the parental strain XC1701 (not shown).

Intactness of the air-dried cells was examined as follows. Among other proteins, $\alpha$-amylase is secreted by the parental strain XC1701, whereas it accumulates in the periplasm in the $x p s D:: \operatorname{Tn} 5$ mutant strain XC1708 $(\mathrm{Hu}$ et al., 1992a). When the antibody against $\alpha$-amylase was included in the immunofluorescence experiments, $\mathrm{XC1701}$ or XC1708(pKC118) showed fluorescence. In

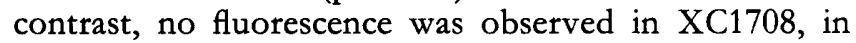
which synthesis of $\alpha$-amylase was demonstrated by a Western blot of the total cell extract (not shown). These results indicated that periplasmic proteins are not detectable under our experimental conditions.

\section{Replacement of the XpsD lipoprotein signal peptide with a nonlipoprotein signal peptide}

In order to study the significance of the lipid moiety of $\mathrm{XpsD}$ in its subcellular location, we replaced the sequence encoding the signal peptide of $\mathrm{XpsD}$ with that from an 


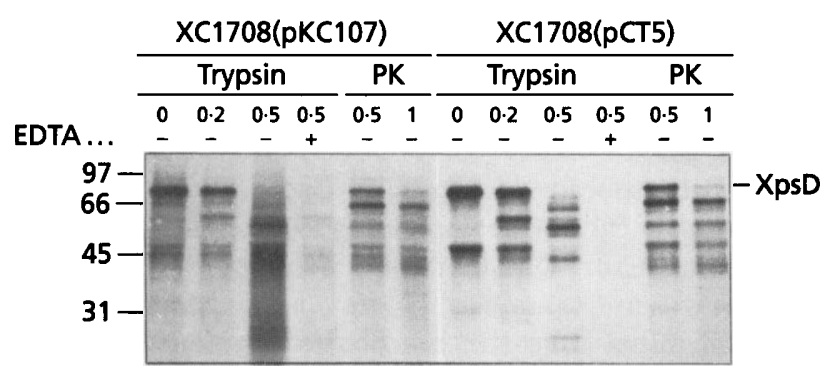

Fig. 5. Comparison of sensitivity of non-fatty-acylated XpsD with wild-type XpsD against trypsin or proteinase $K$ digestion. XC1708(pKC107) and XC1708(pCT5), labelled with $\left.{ }^{[35} \mathrm{S}\right]$ methionine for $30 \mathrm{~min}$, were treated with trypsin or proteinase $K$ (PK) at various concentrations (in $\mathrm{mg} \mathrm{ml}^{-1}$ ), with or without EDTA, as depicted above each lane, followed by immunoprecipitation with anti-LacZ-XpsD antibody, SDS-PAGE and fluorography. - , Digestion without EDTA; +, digestion with the addition of $5 \mathrm{mM}$ EDTA. Numbers marked on the left depict molecular mass standards in $\mathrm{kDa}$.

amy gene of $X$. campestris pv. campestris (Hu et al., 1992b). The newly introduced signal peptide was designed to allow the protein product to be translocated across the inner membrane without lipid modification. The absence of lipid modification was substantiated by palmitate labelling experiments. When the parental XpsD was labelled with $\left[{ }^{3} \mathrm{H}\right]$ palmitate, the variant $\mathrm{XpsD}$ was not labelled (not shown). Its export to the outer membrane was examined as follows.

\section{Subcellular location of non-fatty-acylated XpsD}

The non-fatty-acylated $\mathrm{XpsD}$ produced from XC1708(pCT5) was examined for its subcellular location via fractionation on a sucrose gradient, differential extraction with Triton X-100 and its protease sensitivity in intact cells. Results from all three experiments indicated that the non-fatty-acylated XpsD appeared to be exported to the outer membrane as well as the parental XpsD. The distribution of non-fatty-acylated $\mathrm{XpsD}$ on a sucrose gradient is almost identical to that of the parental XpsD (not shown), disclosing that it is mainly located in the outer membrane. Its fractionation with Triton X-100 also revealed that it is extracted with the outer-membrane vesicles (Fig. 3). Treatment of $\left[{ }^{35} \mathrm{~S}\right]$ methionine-labelled intact XC1708(pKC107) or XC1708(pCT5) with trypsin or proteinase $\mathrm{K}$ revealed no major difference in protease sensitivity between the fatty-acylated $\mathrm{XpsD}$ and the nonfatty-acylated XpsD (Fig. 5). In this particular experiment, the $\mathrm{XpsD}$ protein, with or without lipid modification, was degraded completely with $0.5 \mathrm{mg}$ trypsin $\mathrm{ml}^{-1}$ and almost completely with $1 \mathrm{mg}$ proteinase $\mathrm{K} \mathrm{ml}^{-1}$. Similar trypsin or proteinase $\mathrm{K}$ degradation products were observed in both strains. Minor differences between two trypsintreated $\left(0.5 \mathrm{mg} \mathrm{ml}^{-1}\right)$ samples could be attributed to slight variation in sample sizes. When $5 \mathrm{mM}$ EDTA was included in trypsin treatment, almost all degradation products disappeared in both strains. All these results suggested that lack of fatty-acylation did not provoke any detectable conformational change in $\mathrm{XpsD}$.

\section{Construction of the mutant XpsD genes that produce truncated XpsD proteins XpsD $\Delta$ 414-759 and XpsD $\Delta$ 28-427}

Alignment of $\mathrm{XpsD}$ with its homologues revealed a GS (glycine and serine)-rich region that was only observed in $\mathrm{XpsD}$ and the OutD protein of E. chrysanthemi (Condemine et al., 1992). This GS-rich region in XpsD is located between amino acid residues 347 and 427 . This region was chosen arbitrarily for dividing $\mathrm{XpsD}$ into halves, an $\mathrm{N}$ terminal half and a C-terminal half. In order to produce a $\mathrm{C}$-terminal truncated protein, we introduced a premature termination codon in the cloned $x p s D$ gene, via sitedirected mutagenesis, at amino acid residue 414 of the $\mathrm{XpsD}$ protein. When $\mathrm{pMH} 7$ was introduced into the $x p s D:: \operatorname{Tn} 5$ mutant $\mathrm{XC1708}$, a $45 \mathrm{kDa}$ protein crossreactive with the anti-LacZ-XpsD antibody was produced (Fig. 1a, lane 4).

An internal deletion was created to produce an $\mathrm{N}$-terminal truncated protein, the deletion being from amino acid residue 28 to 427 , so that the truncated protein could be exported via its $\mathrm{N}$-terminal signal peptide sequence. Unfortunately, no cross-reactive material with the expected molecular mass $(38 \mathrm{kDa})$ could be detected with antibody against the LacZ-XpsD fusion protein on a Western blot of the total cell extract of XC1708(pCD105). The possibility that a premature termination codon might have been generated in the mutated region as a result of mutagenesis or cloning has been ruled out from DNA sequencing data. Short labelling followed by immune precipitation was performed to examine protein stability. No conclusion could be reached. Besides protein instability, lack of cross-reactivity between the anti-LacZ$\mathrm{XpsD}$ antibody and the truncated protein XpSD $\Delta 28-427$ could also account for the absence of its detection. Amino acid sequence downstream of residue 588 of XpsD was excluded from the LacZ-XpsD fusion protein, which was used to raise antibody against XpsD. Lack of crossreactivity between antibody against the complete filamentous phage protein $\mathrm{pIV}$ and a truncated protein, pIV $\Delta 15$ 242 , has been observed previously by Russel \& Kaźmierczak (1993).

\section{Subcellular location of the C-terminal truncated protein XpsD $\Delta$ 414-759}

Fractionation via spheroplast formation revealed that the C-terminal truncated protein $\mathrm{XpsD} \Delta 414-759$ was present in both periplasmic and membrane fractions in $X$. campestris pv. campestris (not shown). Sucrose gradient sedimentation analysis indicated that the truncated protein present in membranes appeared in similar fractions as the complete $\mathrm{XpsD}$, cofractionating with the outer-membrane protein OprF (not shown).

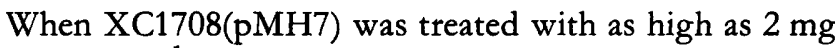
trypsin $\mathrm{ml}^{-1}$, approximately $20 \%$ of the truncated XpsD 


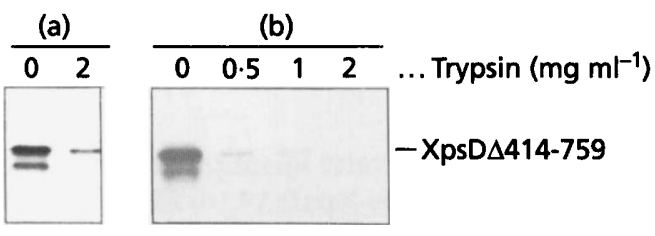

Fig. 6. Protease digestion of $\mathrm{XpsD} \Delta 414-759$. XC1708(pMH7), labelled with ${ }^{35} \mathrm{~S}$ ]methionine for $30 \mathrm{~min}$, was treated with trypsin at various concentrations on ice for $1 \mathrm{~h}$, without (a) or with (b) prior treatment with 5 mM EDTA. All samples were precipitated with antibody against LacZ-XpsD, followed by SDSPAGE and fluorography. Only a portion of the fluorogram is shown.

remained undegraded (Fig. 6a). Complete digestion of the truncated XpsD was observed only when the cells were pretreated with EDTA (Fig. 6b), which presumably permeabilized the outer membrane. These results agreed with the observation that some of the truncated protein $\mathrm{XpsD} \Delta 414-759$ synthesized from $\mathrm{pMH} 7$ was detected in the periplasmic fraction.

The fluorescence observed in anti-LacZ-XpsD antibodylabelled XC1708(pMH7) was almost indistinguishable from that in XC1708(pKC118), which contained the complete, wild-type $\mathrm{XpsD}$, suggesting that some portion of the truncated $\mathrm{XpsD} \Delta 414-759$ is exposed to the cell surface.

\section{Functional assay of non-fatty-acylated XpsD and truncated XPsD proteins}

The extracellular protein secretion property of the transconjugants XC1708(pCT5) and XC1708(pMH7) was tested on XOL plates containing starch or milk. Clear zones appearing around colonies after overnight incubation at $28^{\circ} \mathrm{C}$ indicated secretion of $\alpha$-amylase and protease, respectively. Diameters of the clear zones generated from XC1708(pCT5) were of the same size as those from the parental strain XC1701 as well as from

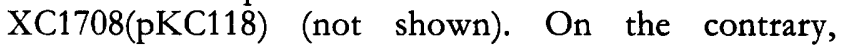

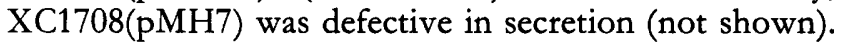
Results from fluorescence experiments also suggested that the truncated XpsD $\Delta 414-759$ was not able to complement the secretion defect in XC1708. In contrast to

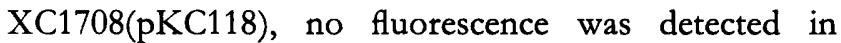

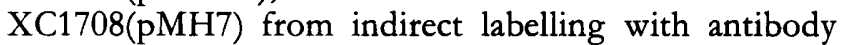
against $\alpha$-amylase.

\section{DISCUSSION}

Two aspects of the subcellular location of $\mathrm{XpsD}$ were pursued in this study. The first was focused on the subcellular location of wild-type XpsD. We demonstrated in this study that XpsD is an outer-membrane protein with part of its sequence exposed to the cell surface. The second aspect concerned the requirement of the lipid moiety of XpsD and its $\mathrm{N}$-terminal or $\mathrm{C}$-terminal halves for localization of $\mathrm{XpsD}$ in the outer membrane. It was shown that fatty acylation is not required for $\mathrm{XpsD}$ to be located in the outer membrane. On the other hand, the Nterminal half of $\mathrm{XpsD}$ polypeptide is sufficient, by itself, for outer-membrane localization. Because the C-terminal half of XpsD cannot be detected with the antibody raised against the LacZ-XpsD fusion protein, its subcellular location was not examined. However, it is homologous to the C-terminal two-thirds of the filamentous phage protein pIV, which was shown to be located in the outer membrane by Russel \& Kaźmierczak (1993).

A $16 \mathrm{kDa}, \mathrm{N}$-terminal fragment of the filamentous phage protein $\mathrm{pIV}$ remained undigested after trypsin digestion of $\mathrm{f1}$-infected E. coli. This fragment was demonstrated to be intrinsically resistant to trypsin and localized in the periplasm (Brissette \& Russel, 1990), suggesting that the N-terminal one-third of pIV may be located in the periplasm. This was confirmed by gene fusion studies of the pIV gene with pho $A$ (Russel \& Kaźmierczak, 1993). Unlike pIV, a C-terminal truncated XpsD protein, $\mathrm{XpsD} \Delta 414-759$, was located in the membrane as well as in the periplasmic fraction. Its periplasmic location could be attributed to its high level of expression. We noticed that $\mathrm{XpsD} \Delta 414-759$ was synthesized at a slightly higher level than the plasmid-encoded wild-type XpsD. The membranous XpsD $\Delta 414-759$ cofractionated with the outermembrane protein $\mathrm{OprF}$ on a sucrose gradient and was susceptible in intact cells to protease digestion and labelling with antibody against the LacZ-XpsD fusion protein. Such difference in subcellular location between the two respective $\mathrm{N}$-terminal portions of $\mathrm{XpsD}$ and $\mathrm{pIV}$ may have significance in their different biological roles, the former being required for extracellular protein secretion and the latter for phage assembly and release (Russel \& Kaźmierczak, 1993). Each $\mathrm{N}$-terminal portion may be involved in interaction with different proteins, $\mathrm{pI}$ in the case of PIV (Russel, 1993). It would be interesting to find out if XpsD interacts with any other protein(s) encoded in the $x p s$ gene cluster.

Despite its wide distribution on sucrose gradients, $\mathrm{XpsD}$ apparently cofractionated with the outer-membrane protein OprF. The peak of the distribution appeared between fractions 20-30, which was not so apparent in the particular experiment shown in Fig. 3. This was because, despite the inclusion of extra amounts of SDS, samples in fractions 20-24 were not solubilized as completely as in other fractions as evidenced from the Coomassie-bluestained gel. XpsD detected in fractions $12-18$ could represent that present in the light tail end of outermembrane distribution, or the XpsD located in the membrane vesicles composed of attachment sites between inner and outer membranes (Ishidate et al., 1986). The observation that almost no XpsD made in XC1701 was extracted with Triton X-100 in the inner-membrane fraction seemed to agree with the former interpretation.

The lipoprotein signal peptide of the $x p s D$ gene product was replaced with a nonlipoprotein signal peptide, plus the first three amino acid residues of the mature protein, derived from the amy gene of $X$. campestris pv. campestris 
(Hu et al., 1992b). Such a construction was designed to avoid aberrant signal peptide processing or inefficient export. Both were observed in the case of the Klebsiella lipoprotein pullulanase when cysteine, the modified amino acid of lipoprotein, alone was substituted (Murooka \& Ikeda, 1989; Kornacker et al., 1991). Sucrose gradient analysis and protease studies indicated that the subcellular location of the variant $\mathrm{XpsD}$ was not significantly different from the parental $\mathrm{XpsD}$, suggesting that the replacement with an authentic nonlipoprotein signal peptide has allowed efficient translocation of $\mathrm{XpsD}$ across the inner membrane. Plate assays for the secretion of $\alpha$ amylase or protease indicated that fatty acylation of $\mathrm{XpsD}$ is probably not essential for its role in protein secretion. Among other homologues, $\mathrm{XpsD}$ is the only known lipoprotein. However, a small outer-membrane protein, PulS, required for pullulanase secretion by $K$. pneumoniae, is also a lipoprotein (d'Enfert \& Pugsley, 1989). Its homologue OutS required for secretion of pectate lyase by $E$. chrysanthemi appeared to be a lipoprotein as well (Condemine et al., 1992). Although we have not tested the ability of $\mathrm{XpsD}$ in substituting its homologues for protein secretion or vice versa, experiments conducted by He $\mathrm{et}$ al. (1991) suggested that sec-dependent secretion systems from different Gram-negative bacteria may not be interchangeable. Before further experiments are conducted, we cannot rule out the possibility that the lipid moiety of $\mathrm{XpsD}$ might be significant in determining the selectivity of secreted proteins or other untested properties, such as efficiency, of the secretion machinery.

The difference in $\mathrm{XpsD}$ protease sensitivity between $X$. campestris pv. campestris and E. coli could be attributed to: (i) difference in cell surface, (ii) different XpsD conformational structures adopted in different species, (iii) presence or absence of other Xps proteins, or (iv) any combinations of the above three. In contrast to the lipopolysaccharides (LPS) of enteric bacteria, no heptose was found in the LPS of $X$. campestris pv. campestris (Volk, 1966). The ladderlike separation pattern of Salmonella typhimurium LPS in SDS-polyacrylamide gels was not observed with $X$. campestris pv. campestris LPS. Instead, three faint bands appeared at the high molecular mass region (Köplin et al., 1993). These observations suggested the presence of distinct features in $X$. campestris pv. campestris LPS, which may influence the accessibility of $\mathrm{XpsD}$ to proteases.

Comparison of the trypsin digestion products of $\mathrm{XpsD}$ revealed differences between $E$. coli and $X$. campestris $\mathrm{pv}$. campestris. A major band with a molecular mass of approximately $60 \mathrm{kDa}$ and two groups of minor bands with smaller molecular masses, one around $45 \mathrm{kDa}$ and the other around $31 \mathrm{kDa}$, appeared in $X$. campestris $\mathrm{pv}$. campestris treated with $1 \mathrm{mg}$ trypsin $\mathrm{ml}^{-1}$ (Fig. 4b, top, left panel) or $0.5 \mathrm{mg}$ trypsin $\mathrm{ml}^{-1}$ (Fig. 5). Such bands were not observed in trypsin-treated E. coli that expressed $\mathrm{XpsD}$ (Fig. 4a). These differences are probably not related to the other Xps proteins. Almost identical protease digestion products were observed in XC1708(pKC118) and in XC17433(pKC118) (not shown). The latter contained no Xps proteins other than XpsD. Presumably, different conformations of the XpsD external loop structures in different host cells could account for the observed differences.

Pullulanase produced by $K$. oxytoca was detected on the cell surface by immunodetection (d'Enfert $e t$ al., 1987). In E. coli expressing pullulanase, it was detected on the cell surface as well only when the genes required for its secretion were present. These results suggested that the attachment of pullulanase on the cell surface may be an intermediary step in pullulanase secretion. However, when the lipoprotein signal peptide of pullulanase was replaced with the nonlipoprotein signal peptide of MalE, it was shown that, in contrast to fatty-acylated pullulanase, non-fatty-acylated pullulanase was secreted directly into the milieu without prior attachment to the cell surface (Poquet et al., 1993). Further studies are required to assess the significance of detecting secreted, nonlipoprotein $\alpha$ amylase on the cell surface of $X$. campestris pv. campestris. We considered the absence of surface-exposed $\alpha$-amylase in the secretion-defective mutant strain XC1708 as an indication of intactness of cells in immunofluorescence experiments. The validity of such control experiments is probably not influenced by the lack of knowledge about the significance of surface-exposed $\alpha$-amylase in secretioncompetent strains.

A protein with an apparent molecular mass of $48 \mathrm{kDa}$ repeatedly appeared along with the $77 \mathrm{kDa} \mathrm{XpsD}$, either on a Western blot of $X$. campestris pv. campestris cell extracts or on an autoradiogram of immunoprecipitated, $\left[{ }^{3} \mathrm{H}\right]$ palmitate-labelled cells. It was not detected in the strain XC17433, where the entire $x p$ s gene cluster was deleted (not shown). It was discernible in the $x p s D:: \operatorname{Tn} 5$ mutant XC1708, where $\operatorname{Tn} 5$ was inserted close to Cterminal end of XpsD (Fig. 1a, lane 2). Replacement of the $\mathrm{XpsD}$ lipoprotein signal peptide with a nonlipoprotein signal peptide did not abolish the appearance of the $48 \mathrm{kDa}$ protein, which, however, was no longer labelled with $\left[{ }^{3} \mathrm{H}\right]$ palmitate. These observations suggested that this protein probably contains the $\mathrm{N}$-terminal end of $\mathrm{XpsD}$ and its production was not influenced by the absence of lipid modification at the $\mathrm{N}$-terminus or $\operatorname{Tn} 5$ insertion near the C-terminal end. It has been demonstrated that the $d n a X$ gene of $E$. coli encodes two DNA polymerase III holoenzyme subunits, $\tau(71 \mathrm{kDa})$ and $\gamma$ $(47 \mathrm{kDa})$, that share an identical $\mathrm{N}$-terminal sequence. They are produced from the same ORF as a result of $a-1$ translational frameshifting event (Blinkowa \& Walker, 1990; Tsuchihashi \& Kornberg, 1990). A stretch of six adenines and a downstream hairpin structure were noted to flank the termination codon of the $\gamma$ subunit (Tsuchihashi \& Kornberg, 1990). Similar structures were associated with expression of the genes of the bacterial insertion sequence IS 1 and the $\operatorname{tr} p R$ gene of $E$. coli (Escoubas $e t$ al., 1991 ; Benhar et al., 1992). The latter was later demonstrated to be caused by a translational bypassing event and unrelated with the hexa-adenine-stretch (Benhar \& Engelberg-Kulka, 1993; Engelberg-Kulka \& SchoulakerSchwarz, 1994). Examination of the $x p s D$ gene nucleotide sequence revealed a stretch of six adenines at nucleotides 1644-1649, counted from the adenine of the initiation codon. A termination codon in the -1 or +1 reading 
frame appears within 30 nucleotides downstream of the hexa-adenine-stretch. However, translational termination in either case would produce a protein with a molecular mass of $55 \mathrm{kDa}$. Besides, no reduction in the production of the $48 \mathrm{kDa}$ protein was observed from two mutated $x p s D$ genes, one with two-base substitutions (C AAG $\mathrm{AA}$ ) interrupting the hexa-adenine-stretch and the other with an inframe deletion removing the hexa-adeninestretch plus some flanking sequences (data not shown). It is unlikely that the appearance of the $48 \mathrm{kDa}$ protein is due to a frameshifting event occurring downstream of the hexa-adenine-stretch in the $x p s D$ gene. Other possible causes that might have prompted the production of the $48 \mathrm{kDa}$ protein, such as translational bypassing or proteolytic cleavage, have not been ruled out. Determination of the origin of the $48 \mathrm{kDa}$ protein may provide clues as to whether it plays any role in extracellular protein secretion.

\section{ACKNOWLEDGEMENTS}

N. T. Hu would like to dedicate this work to the late Philip J. Bassford, Jr. The authors would also like to thank M. Russel for reading the manuscript, U. Henning for kindly sending antibody against E. coli OmpA, P. Ray and E. A. Parrish for kind help in raising the antibody against $\alpha$-amylase, Y.-N. Chang for suggesting the SOE method, D. Bauer for providing plasmid pCPP30, K.-C. Wang for constructing plasmids pKC101, pKC107 and pKC118, D.-Y. Chen for pCD105 and the $48 \mathrm{kDa}$ protein studies and C.-H. Lin for determining the partial DNA sequence of pCD105. This work was supported by a grant from National Science Council of Republic of China: NSC82-0211-B005-037.

\section{REFERENCES}

Akrim, M., Bally, M., Ball, G., Tommassen, J., Teerink, H., Filloux, A. \& Lazdunski, A. (1993). Xcp-mediated protein secretion in Pseudomonas aeruginosa: identification of two additional genes and evidence for regulation of $x c p$ gene expression. Mol Microbiol 10, 431-443.

Allaoui, A., Sansonetti, P. J. \& Parsot, C. (1992). MxiJ, a lipoprotein involved in secretion of Shigella Ipa invasins, is homologous to YscJ, a secretion factor of the Yersinia Yop proteins. J Bacteriol 174, 7661-7669.

Allaoui, A., Sansonetti, P. J. \& Parsot, C. (1993). MxiD, an outer membrane protein necessary for the secretion of the Sbigella flexneri Ipa invasins. Mol Microbiol 7, 59-68.

Arlat, M., Van Gijsegem, F., Huet, J. C., Pernollet, J. C. \& Boucher, C. A. (1994). PopA1, a protein which induces a hypersensitive-like response on specific Petunia genotypes, is secreted via the Hrp pathway of Pseudomonas solanacearum. EMBO J 13, 543-553.

Bally, M., Ball, G., Badere, A. \& Lazdunski, A. (1991). Protein secretion in Pseudomonas aeruginosa: the $x c p A$ gene encodes an integral inner membrane protein homologous to Klebsiella pneumoniae secretion function protein PulO. J Bacteriol 173, 479-486.

Bally, M., Filloux, A., Akrim, M., Ball, G., Lazdunski, A. \& Tommassen, J. (1992). Protein secretion in Pseudomonas aeruginosa: characterization of seven $x c p$ genes and processing of secretory apparatus components by prepilin peptidase. Mol Microbiol 6, 1121-1131.

Benhar, I. \& Engelberg-Kulka, H. (1993). Frameshifting in the expression of the $E$. coli $\operatorname{trpR}$ gene occurs by the bypassing of a segment of its coding sequence. Cell 72, 121-130.

Benhar, I., Miller, C. \& Engelberg-Kulka, H. (1992). Frameshifting in the expression of the Escherichia coli trpR gene. Mol Microbiol 6, 2777-2784.

Blinkowa, A. L. \& Walker, J. R. (1990). Programmed ribosomal frameshifting generates the Escherichia coli DNA polymerase III $\gamma$ subunit from within the $\tau$ subunit reading frame. Nucleic Acids Res $18,1725-1729$.

Brissette, J. L. \& Russel, M. (1990). Secretion and membrane integration of a filamentous phage-encoded morphogenetic protein. $J$ Mol Biol 211, 565-580.

Condemine, G., Dorel, C., Hugouvieux-Cotte-Pattat, N. \& RobertBaudouy, J. (1992). Some of the out genes involved in the secretion of pectate lyases in Erwinia chrysanthemi are regulated by kdgR. Mol Microbiol 6, 3199-3211.

Cowan, S. W., Schrimer, T., Rummel, G., Steiert, M., Ghosh, R., Pauptit, R. A., Jansonius, J. N. \& Rosenbusch, J. P. (1992). Crystal structures explain functional properties of two $E$. coli porins. Nature 358, 727-733.

Dums, F., Dow, J. M. \& Daniels, M. J. (1991). Structural characterization of protein secretion genes of the bacterial phytopathogen Xanthomonas campestris pathovar campestris: relatedness to secretion systems of other gram-negative bacteria. Mol \& Gen Genet 229, 357-364.

d'Enfert, C. \& Pugsley, A. P. (1989). Klebsiella pneumoniae pulS gene encodes an outer membrane lipoprotein required for pullulanase secretion. J Bacteriol 171, 3673-3679.

d'Enfert, C., Ryter, A. \& Pugsley, A. P. (1987). Cloning and expression in Escherichia coli of the Klebsiella pneumoniae genes for production, surface localization and secretion of the lipoprotein pullulanase. EMBO J 6, 3531-3538.

d'Enfert, C., Reyss, I., Wandersman, C. \& Pugsley, A. P. (1989). Protein secretion by gram-negative bacteria: characterization of two membrane proteins required for pullulanase secretion by Eschericbia coli K-12. J Biol Chem 264, 17462-17468.

Engelberg-Kulka, H. \& Schoulaker-Schwarz, R. (1994). Regulatory implications of translational frameshifting in cellular gene expression. Mol Microbiol 11, 3-8.

Escoubas, J. M., Prère, M. F., Fayet, O., Salvignol, I., Galas, D., Zerbib, D. \& Chandler, M. (1991). Translational control of transposition activity of the bacterial insertion sequence IS1. EMBO J 10, 705-712.

Filloux, A., Bally, M., Ball, G., Akrim, M., Tommassen, J. \& Lazdunski, A. (1990). Protein secretion in Gram-negative bacteria: transport across the outer membrane involves common mechanisms in different bacteria. EMBO J 9, 4323-4329.

Guzzo, J., Duong, F., Wandersman, C., Murgier, M. \& Lazdunski, A. (1991). The secretion genes of Pseudomonas aeruginosa alkaline protease are functionally related to those of Erwinia chrysanthemi proteases and Escherichia coli $\alpha$-haemolysin. Mol Microbiol 5, 447-453.

Hancock, R. E. W., Siehnel, R. \& Martin, N. (1990). Outer membrane proteins of Pseudomonas. Mol Microbiol 4, 1069-1075.

Harlow, E. \& Lane, D. (1988). Antibodies: a Laboratory Manual, pp. 119. Cold Spring Harbor, NY: Cold Spring Harbor Laboratory.

Hayashi, S. \& Wu, H. C. (1990). Lipoproteins in bacteria. J Bioenerg Biomembr 22, 451-471. 
He, S. Y., Lindeberg, M., Chatterjee, A. K. \& Collmer, A. (1991). Cloned Erwinia chrysanthemi out genes enable Escherichia coli to selectively secrete a diverse family of heterologous proteins to its milieu. Proc Natl Acad Sci US A 88, 1079-1083.

He, S. Y., Huang, H.-C. \& Collmer, A. (1993). Pseudomonas syringae pv. syringae harpin (pss): a protein that is secreted via the Hrp pathway and elicits the hypersensitive response in plants. Cell 73, 1255-1266.

Holland, I. B., Blight, M. A. \& Kenny, B. (1990). The mechanism of secretion of hemolysin and other polypeptides from gram-negative bacteria. J Bioenerg Biomembr 22, 473-491.

Horton, R. M., Hunt, H. D., Ho, S. N., Pullen, J. K. \& Pease, L. R. (1989). Engineering hybrid genes without the use of restriction enzymes: gene splicing by overlap extension. Gene 77, 61-68.

Howard, S. P., Critch, J. \& Bedi, A. (1993). Isolation and analysis of eight exe genes and their involvement in extracellular protein secretion and outer membrane assembly in Aeromonas bydrophila. $J$ Bacteriol 175, 6695-6703.

Hu, N.-T., Hung, M.-N., Chiou, S.-J., Tang, F., Chiang, D.-C., Huang, H.-Y. \& Wu, C.-Y. (1992a). Cloning and characterization of a gene required for the secretion of extracellular enzymes across the outer membrane by Xanthomonas campestris pv. campestris. J Bacteriol 174, 2679-2687.

Hu, N.-T., Hung, M.-N., Huang, A.-M., Tsai, H.-F., Yang, B.-Y., Chow, T.-Y. \& Tseng, Y.-H. (1992b). Molecular cloning, characterization and nucleotide sequence of the gene for secreted $\alpha$-amylase from Xanthomonas campestris pv. campestris. J Gen Microbiol 138, 1647-1655.

Ishidate, K., Creeger, E. S., Zrike, J., Deb, S., Glauner, B., MacAlister, T. J. \& Rothfield, L. I. (1986). Isolation of differentiated membrane domains from Escherichia coli and Salmonella typbimurium, including a fraction containing attachment sites between the inner and outer membranes and the murein skeleton of the cell envelope. J Biol Chem 261, 428-443.

Jiang, B. \& Howard, S. P. (1992). The Aeromonas bydrophila exeE gene, required both for protein secretion and normal outer membrane biogenesis, is a member of a general secretion pathway. Mol Microbiol 6, 1351-1361.

Kaźmierczak, B. I., Mielke, D. L., Russel, M. \& Model, P. (1994). pIV, a filamentous phage protein that mediates phage export across the bacterial cell envelope, forms a multimer. $J$ Mol Biol 238, 187-198.

Koehler, J. E., Birkelund, S. \& Stephens, R. S. (1992). Overexpression and surface localization of the Chlamydia trachomatis major outer membrane protein in Escherichia coli. Mol Microbiol 6, 1087-1094.

Koplin, R., Wang, G., Hotte, B., Priefer, U. B. \& Puhler, A. (1993). A 3.9-kb DNA region of Xanthomonas campestris pv. campestris that is necessary for lipopolysaccharide production encodes a set of enzymes involved in the synthesis of dTDP-rhamnose. J Bacteriol 175, 7786-7792.

Kornacker, M. G., Faucher, D. \& Pugsley, A. P. (1991). Outer membrane translocation of the extracellular enzyme pullulanase in Escherichia coli $\mathrm{K} 12$ does not require a fatty acylated N-terminal cysteine. $J$ Biol Chem 266, 13842-13848.

Létoffé, S., Delepelaire, P. \& Wandersman, C. (1990). Protease secretion by Erwinia chrysanthemi: the specific secretion functions are analogous to those of Escherichia coli $\alpha$-haemolysin. EMBO J $\mathbf{9}$, 1375-1382.

Lindeberg, M. \& Collmer, A. (1992). Analysis of eight out genes in a cluster required for pectic enzyme secretion by Erwinia chrysan- themi: sequence comparison with secretion genes from other gramnegative bacteria. $J$ Bacteriol 174, 7385-7397.

Mead, D. A., Szczesna-Skorupa, E. \& Kemper, B. (1986). Singlestranded DNA 'blue' T7 promoter plasmids: a versatile tandem promoter system for cloning and protein engineering. Protein Eng 1, 67-76.

Michiels, T., Vanooteghem, J.-C., de Rouvroit, C. L., China, B., Gustin, A., Boudry, P. \& Cornelis, G. R. (1991). Analysis of virC, an operon involved in the secretion of Yop proteins by Yersinia enterocolitica. J Bacteriol 174, 4994-5009.

Miller, J. H. (1972). Experiments in Molecular Genetics, pp. 431-434. Cold Spring Harbor, NY: Cold Spring Harbor Laboratory.

Murata, H., Fons, M., Chatterjee, A., Collmer, A. \& Chatterjee, A. K. (1990). Characterization of transposon insertion Out ${ }^{-}$mutants of Erwinia carotovora subsp. carotovora defective in enzyme export and of a DNA segment that complements out mutation in $E$. carotovora subsp. carotovora, E. carotovora subsp. atroseptica, and Erwinia chrysanthemi. J Bacteriol 172, 2970-2978.

Murooka, Y. \& Ikeda, R. (1989). Biosynthesis and secretion of pullulanase, a lipoprotein from Klebsiella aerogenes. J Biol Chem 264, 17524-17531.

Poquet, I., Faucher, D. \& Pugsley, A. P. (1993). Stable periplasmic secretion intermediate in the general secretory pathway of Escherichia coli. EMBO J 12, 271-278.

Pugsley, A. P. (1993). The complete general secretory pathway in gram-negative bacteria. Microbiol Rev 57, 50-108.

Pugsley, A. P., d'Enfert, C., Reyss, I. \& Kornacker, M. G. (1990). Genetics of extracellular protein secretion by Gram-negative bacteria. Annu Rev Genet 24, 67-90.

Reeves, P. J., Whitcombe, D., Wharam, S., Gibson, M., Allison, G., Bunce, N., Barallon, R., Douglas, P., Mulholland, V., Stevens, S., Walker, D. \& Salmond, G. P. C. (1993). Molecular cloning and characterization of 13 out genes from Erwinia carotovora subspecies carotovora: genes encoding members of a general secretion pathway (GSP) widespread in Gram-negative bacteria. Mol Microbiol 8, 443-456.

Russel, M. (1993). Protein-protein interactions during filamentous phage assembly. J Mol Biol 231, 689-697.

Russel, M. (1994). Mutants at conserved positions in gene IV, a gene required for assembly and secretion of filamentous phages. Mol Microbiol 14, 357-369.

Russel, M. \& Kaźmierczak, B. (1993). Analysis of the structure and subcellular location of filamentous phage pIV. J Bacteriol 175, 3998-4007.

Salmond, G. P. C. \& Reeves, P. J. (1993). Membrane traffic wardens and protein secretion in gram-negative bacteria. Trends Biochem Sci 18, 7-12.

Tommassen, J. \& Lugtenberg, B. (1984). Amino terminus of outer membrane PhoE protein: localization by use of a bla-phoE hybrid gene. $J$ Bacteriol 157, 327-329.

Tsuchihashi, Z. \& Kornberg, A. (1990). Translational frameshifting generates the $\gamma$ subunit of DNA polymerase III holoenzyme. Proc Natl Acad Sci US A 87, 2516-2520.

Ullstrom, C. A., Siehnel, R., Woodruff, W., Steinbach, S. \& Hancock, R. E. W. (1991). Conservation of the gene for outer membrane protein OprF in the family Pseudomonadaceae: sequence of the Pseudomonas syringae oprF gene. J Bacteriol 173, 768-775.

Van Gijsegem, F., Genin, S. \& Boucher, C. (1993). Conservation of secretion pathways for pathogenicity determinants of plant and animal bacteria. Trends Microbiol 1, 175-180. 
Vieira, J. \& Messing, J. (1987). Production of single-stranded plasmid DNA. Methods Enzymol 153, 3-11.

Volk, W. A. (1966). Cell wall lipopolysaccharides from Xanthomonas species. J Bacteriol 91, 39-42.

Wandersman, C. (1992). Secretion across the bacterial outer membrane. Trends Genet 8, 317-322.

Wei, Z.-M., Laby, R. J., Zumoff, C. H., Bauer, D. W., He, S. Y., Collmer, A. \& Beer, S. V. (1992). Harpin, elicitor of the hypersensitive response produced by the plant pathogen Erwinia amylovora. Science $257,85-88$.
Weiss, M. S., Abele, U., Weckesser, J., Welte, W., Schiltz, E. \& Schultz, G. E. (1991). Molecular architecture and electrostatic properties of a bacterial porin. Science 254, 1627-1630.

Woodruff, W. A. \& Hancock, R. E. W. (1989). Pseudomonas aeruginosa outer membrane protein $F$ : structural role and relationship to the Escherichia coli OmpA protein. J Bacteriol 171, 3304-3309.

Received 31 October 1994; revised 20 February 1995; accepted 22 February 1995. 